\title{
INTEGRASI RADIO FREQUENCY IDENTIFICATION (RFID) DAN HAULING TRACKING SYSTEM (HTS) DALAM OPTIMASI OPERASIONAL PENGANGKUTAN DAN PENCAMPURAN BATUBARA PT ADARO INDONESIA
}

\author{
Arief Andarwan \\ Coal Production and Product Assembly Department, Mining Division \\ PT Adaro Indonesia, Tanjung Tabalong, Kalimantan Selatan \\ arief.andarwan@adaro.com
}

\begin{abstract}
ABSTRAK
Proses pengangkutan dan pencampuran batubara di PT Adaro Indonesia terbilang cukup unik, menggunakan sistem 'blending berjalan", proses pencampuran dilakukan dengan mengatur waktu kedatangan alat pengangkut batubara di terminal fasiltas pemrosesan batubara dan pengisian tongkang agar tiba sesuai dengan waktu yang direncanakan. Untuk menunjang proses optimasi agar menghasilkan kualitas pencampuran yang on spec dan on time dibutuhkan sistem monitoring material, method dan machine yang mumpuni. Teknologi Radio Frequency Identification (RFID) dipilih karena mampu menghasilkan komunikasi data yang cepat. Komponen utama RFID adalah alat pembaca (reader) dan alat penanda (tagger). Alat pembaca dirakit secara elektronik dan beroperasi dengan memanfaatkan sumber energi panas matahari konversi dari solar cell dan ditempatkan di setiap titik strategis di jalur pengangkutan. Alat tagger ditempatkan pada semua alat pengangkut batubara (trailer). Sistem software dan database dibuat secara lokal dan terintegrasi ke pusat database yang terhubung melalui topologi jaringan. Semua transaksi kegiatan pengangkutan mulai dari alat angkut dalam posisi kosong, pengisian, penimbangan sampai penumpahan atau penumpukan diproses secara online dan real time. Sistem ini juga diintegrasikan dengan aplikasi tracking monitoring yang dibuat dan dikembangkan untuk pemantauan data secara real time oleh semua pihak yang terlibat dalam rantai pasok operasional pengangkutan dan pencampuran batubara.Implementasi integrasi teknologi yang disusun berdasarkan analisa kebutuhan bisnis proses ini memberikan dampak langsung dan tidak langsung. Secara biaya pengadaan dan perawatan, tools ini lebih murah dari produk pasaran yang ditawarkan. Dari segi kualitas menghasilkan peningkatan presisi pencampuran. Sisi operasional juga memberikan penghematan dari proses kerja yang efisien dengan peningkatan produktivitas alat angkut. Tindakan perbaikan yang berkelanjutan dan tepat sasaran dari aktivitas pengangkutan dan pencampuran juga dapat dilakukan karena data evaluasi yang dihasilkan dari integrasi teknologi ini valid dan dapat diandalkan.
\end{abstract}

Kata Kunci : RFID, Coal Hauling, Coal Blending, Hauling Tracking System

\begin{abstract}
Coal hauling and mixing in PT Adaro Indonesia is fairly unique, using an "on the way mixing" system, the mixing process is operated by setting the arrival time of the coal truck at coal processing and barge loading terminal facility so that truck arrived according to planned time. In order to support the optimization process to produce optimum quality mixing that is on spec and on time, require capable monitoring system of material, method and machine. Radio Frequency Identification (RFID) technology was chosen because it is able to produce fast data communications. The main components of RFID are reader and tagger. The reader is electronically assembled and operated by using thermal energy conversion from solar cell which placed at each strategic point along hauling road. The tagger is placed on every coal truck (trailer). The software and database system is created locally and integrated into central database that connected through network topology. All transaction from hauling activity starting from the
\end{abstract}


trucks at empty position, loading, passing, weighing until dumping are processed online and real time. This system also integrated with tracking monitoring application that is established and developed for real time monitoring by all parties involved in coal supply chain. The implementation of this technology integration that based on business needs analysis has direct and indirect impact. In terms of investment and maintenance costs, these tools are cheaper than commonly product offered in industrial market. From quality aspect results, it gives enhancement of mixing precision. The operational side also provides saving from efficient working process by increasing truck productivity. Continuous and accurate corrective action from coal hauling and blending operation can also be done because data evaluation that generated from this integrated technology are valid and reliable.

Keyword: RFID, Coal Hauling, Coal Blending, Hauling Tracking System

\section{A. PENDAHULUAN}

Proses blending atau pencampuran batubara dilakukan dengan menggabungkan dua atau lebih tonase batubara tertentu dengan kualitas berbeda. Batubara memiliki beberapa parameter kualitas yaitu sifat fisik dan kimia yang mempengaruhi potensi kegunaan nya. Parameter tersebut antara lain Caloric Value (CV), Total Moisture (TM), Total Sulfur (TS) dan Ash. Variasi harga produk batubara di pasar global ditentukan oleh parameter kualitasnya. Proses pencampuran harus dilakukan dengan optimal yaitu dengan usaha yang efisien dan hasil yang maksimal. Dengan proses blending yang optimal akan menghasilkan profit yang maksimal dan produk batubara yang memenuhi persyaratan pelanggan.

Proses blending batubara di PT Adaro Indonesia dilakukan dengan mencampur sejumlah batubara agar sesuai dengan spesifikasi dan parameter kualitas yang diinginkan. Batubara diangkut dari ROM menuju ke terminal pemrosesan menggunakan alat angkut trailer double vessel dengan kapasitas 135 ton yang beroperasi non stop 24 jam. Batubara yang diangkut dari ROM berjenis uncrushed atau masih berbentuk hasil galian dan belum dilakukan sizing dan pemrosesan lain. Jenis batubara yang dicampur terdiri dari lebih 37 jenis spesifikasi atau disebut raw material yang tersimpan di 12 tempat penumpukan stockpile/ROM (Run of Mine). Waktu kedatangan trailer bermuatan di terminal pemrosesan yang bermuatan raw material tertentu dari ROM disesuaikan dengan waktu sandar dan pengisian tongkang. Tiap tongkang/barge diisi dengan raw material batubara yang sesuai dengan spesifikasi akhir (end product) yang diminta dan direncanakan. Tongkang yang telah diisi kemudian disalurkan ke kapal yang lebih besar (mother vessel) atau langsung disalurkan ke pembeli.

Dalam 24 jam proses pengangkutan dan pencampuran raw material, banyak faktor penghambat yang dapat mempengaruhi keberhasilan kuantitas dan kualitas pencampuran. Faktor seperti produktivitas yang terganggu akibat stand by dan idle time trailer karena pergantian gilir kerja operator, match factor dengan alat muat di ROM yang tidak sesuai, match factor dengan crusher capacity di terminal pemrosesan yang tidak sinkron, hambatan di jalur pengangkutan, perubahan urutan kedatangan tongkang dan masih banyak hambatan lain nya dalam rantai pasok pengiriman batubara.

Dengan variasi spesifikasi batubara yang banyak dan permintaan pasar yang beragam maka dibutuhkan tata kelola perencanaan, implementasi dan evaluasi yang cepat dan terintegrasi agar dapat menghasilkan keunggulan dan efisiensi proses dan hasil. Dibutuhkan suatu perangkat dan teknologi untuk menunjang proses optimasi.pengangkutan dan pencampuran di lingkup operasional PT Adaro Indonesia. 


\section{B. METODOLOGI}

Ide pembuatan dan pengimplementasian teknologi didasarkan pada metodologi kaizen / PDCA (Plan Do Check Action) untuk proses perbaikan dalam bisnis proses pengangkutan dan pencampuran batubara di PT Adaro Indonesia. Pada siklus PDCA dilakukan pencarian akar masalah dengan root cause analysis terhadap permasalahan yang dominan mempengaruhi performance indicator, memvalidasi penyebab lalu merencanakan solusi dan alternatifnya. Tempat atau area perbaikan adalah lingkup operasional PT. Adaro Indonesia pada bisnis proses Departemen Coal Production and Product Assembly. Adapun data yang digunakan adalah data kuantitatif dan waktu pelaksanaan adalah dari tahun 2015 sampai sekarang (2019). Tahapan metodologi yang diadopsi dari metode kaizen dituangkan dalam sembilan langkah ADARO-PDCA:

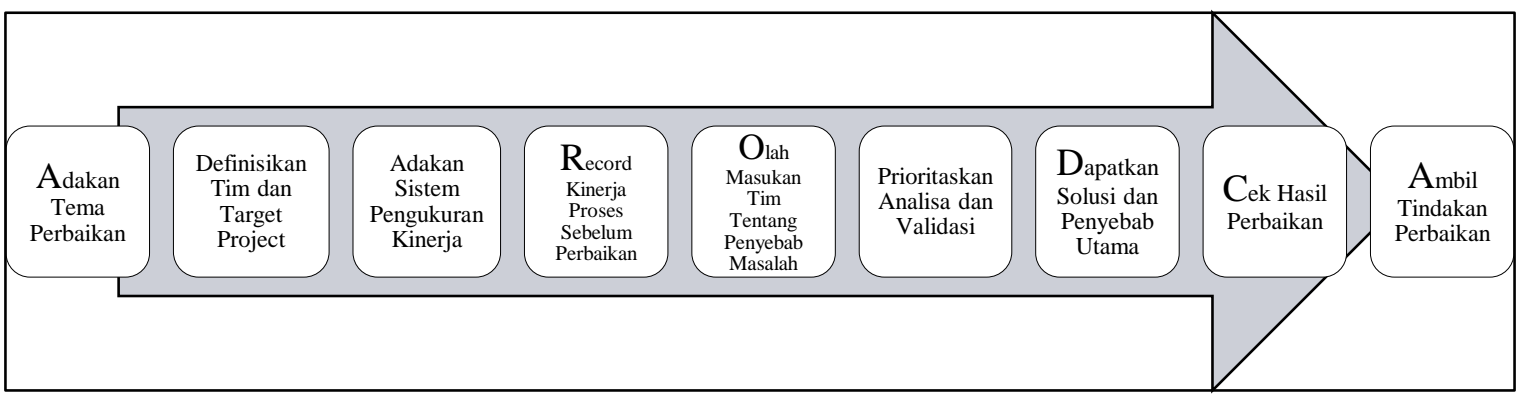

Gambar 1. Metodologi

\section{HASIL DAN PEMBAHASAN}

Dari hasil penelusuran kinerja proses sebelum perbaikan didapatkan bahwa kebutuhan bisnis proses adalah sebuah sistem meliputi alat deteksi dan record data kualitas-kuantitas batubara dan parameter produksi lain nya yang bisa dengan cepat diproses serta disajikan dalam dashboard monitoring online bersama dengan data penunjang lain dalam bisnis proses pengangkutan dan pencampuran batubara. Secara terperinci sistem ini harus mendukung kebutuhan dispatching untuk peningkatan produktivitas unit trailer yang beroperasi, mengintegrasikan data hauling activity, mempercepat pemrosesan dan penyajian data serta menghilangkan human error akibat proses kerja yang manual.

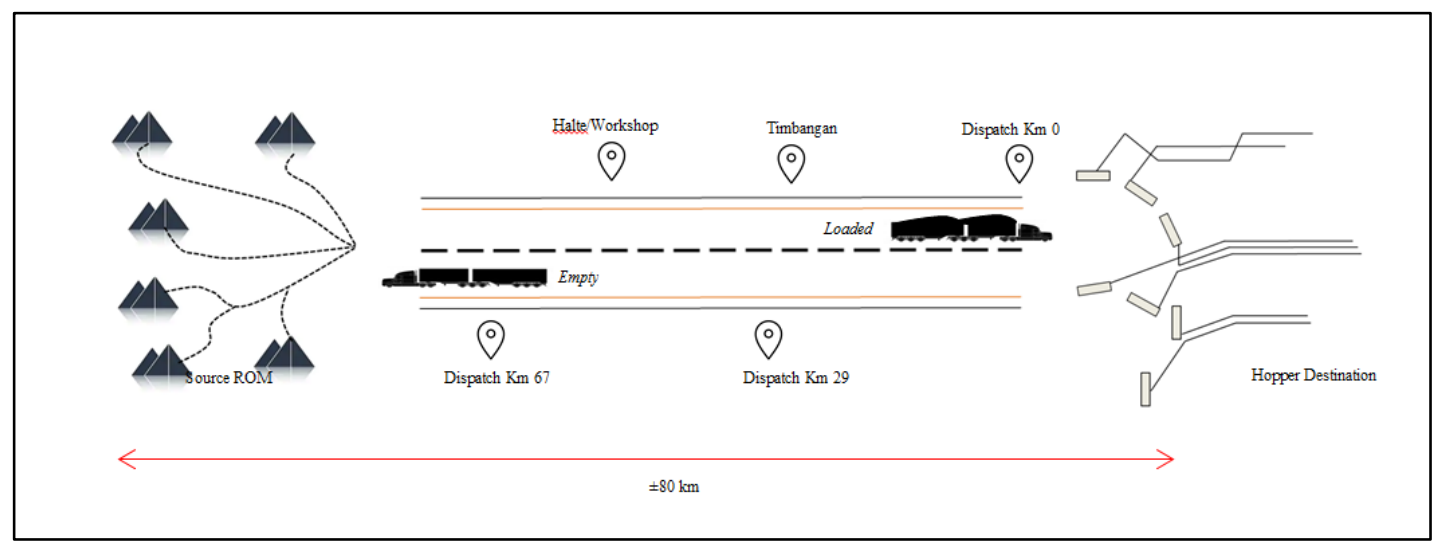

Gambar 2. Ilustrasi operasional pengangkutan dan pencampuran batubara di PT Adaro Indonesia

Banyak nya jumlah trailer yang beroperasi, raw material yang bervariasi dan tersebar di banyak tempat, serta dengan panjang nya jalur pengangkutan maka dibutuhkan fleet management system yang dapat membantu kegiatan operasional. RFID (Radio Frequency Identification) adalah perangkat komunikasi data yang menggunakan gelombang radio pada spektrum elektromagnetik untuk mengidentifikasi suatu objek yang dipasang alat penanda dengan metode identifikasi unik 
oleh perangkat pembaca (reader/transceiver). Keunggulan utama sistem RFID yakni komunikasi data yang cepat sesuai dengan kebutuhan perbaikan proses operasional yang membutuhkan kontrol presisi yang cepat dan mumpuni. Sistem RFID yang dibangun dan diterapkan pada kegiatan pengangkutan dan pencampuran batubara PT Adaro Indonesia terdiri dari komponen hardware, software dan jaringan.

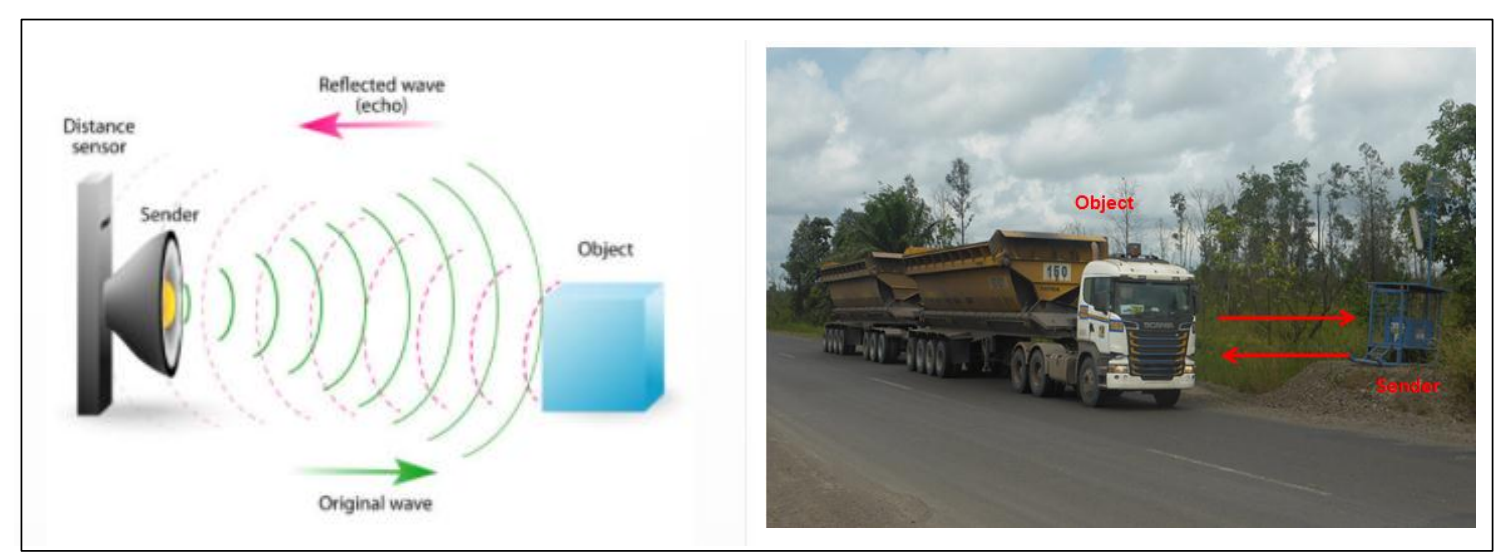

Gambar 3. Ilustrasi sistem kerja RFID

Komponen hardware utama yaitu reader dan tagging card. Reader yang dipilih adalah jenis reader active super high frequency 2.4 Ghz. Sumber energi reader berasal dari energi listrik yang dikonversi dari sinar matahari menggunakan panel solar cell. Komponen reader dirangkai secara elektronik. Energi listrik photovoltatic dari solar cell disalurkan menuju ke controller charger sebagai pengatur tegangan keluar menuju baterai. Baterai digunakan sebagai tempat penyimpanan energi listrik. Baterai yang dipakai adalah jenis VRLA (Valve Regulated Lead Acid) atau istilah pasar lebih dikenal dengan baterai kering atau aki tertutup. Dari baterai, komponen dihubungkan ke power inverter untuk mengubah tegangan searah menjadi tegangan bolak balik. Dari power inverter arus dialirkan menuju perangkat reader, POE switch dan RTC. POE (Power Over Ethernet) switch berfungsi untuk menerima dan mengirimkan data yang dihubungkan menggunakan kabel ethernet/kabel jaringan. Sedangkan RTC (Real Time Clock) adalah komputer kecil yang berfungsi menyimpan sementara data hasil bacaan RFID reader apabila terjadi gangguan jaringan saat reader mengirimkan data ke server pusat, reader akan mengirimkan data ke server saat jaringan kembali normal. Semua komponen tersebut ditempatkan pada kerangkeng sebagai satu kesatuan bersama dengan antena sectoral dan antena grid. Antena sectoral berfungsi sebagai penangkap sinyal radio dari tagging card. Sedangkan antena grid adalah komponen untuk mengirimkan data ke server pusat.

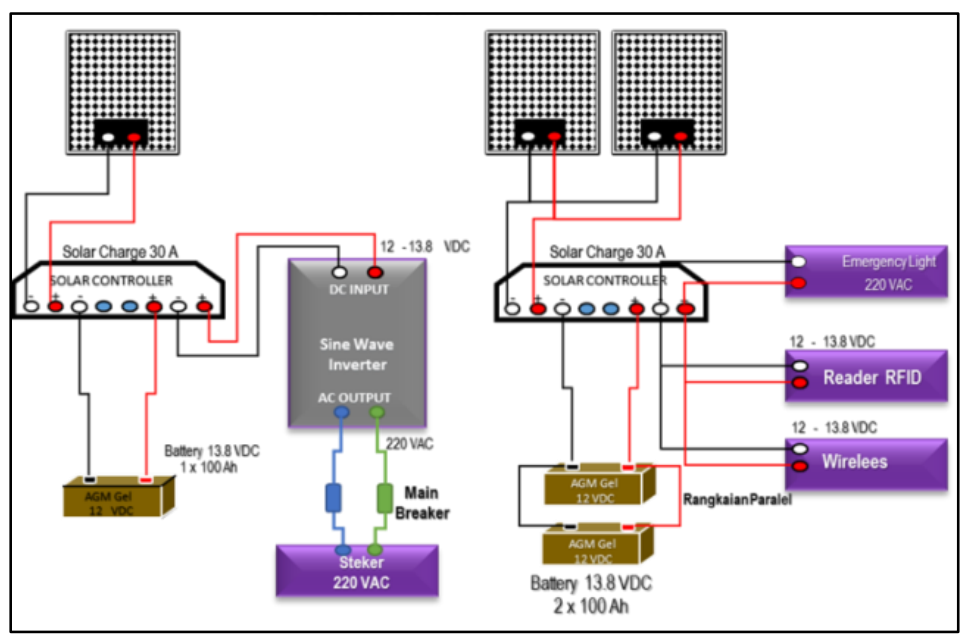

Gambar 4. Rangkaian elektronik reader RFID 


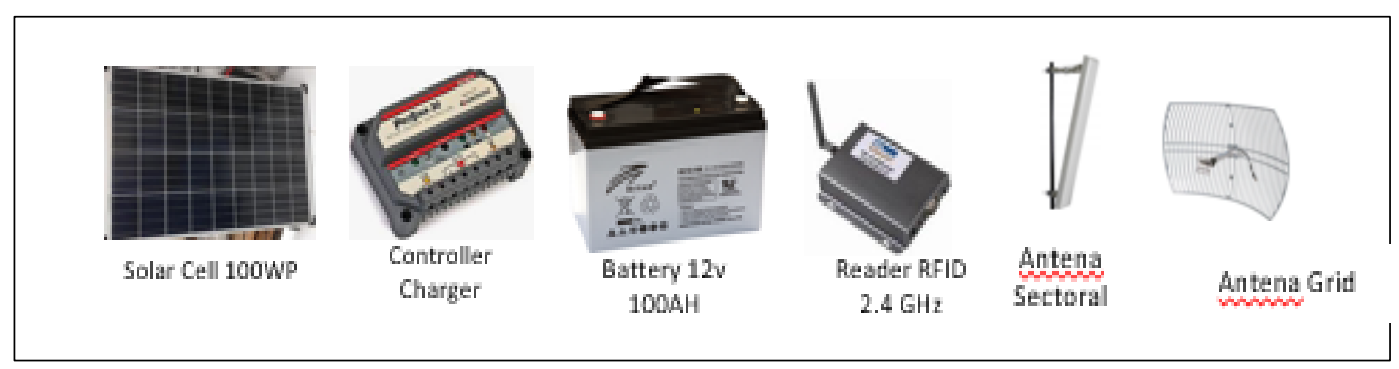

Gambar 5. Komponen elektronik reader RFID

Komponen software yang dipakai yaitu SQL Server Express, Database dan aplikasi bernama BarClient. Aplikasi dan database Barclient terdiri dari komponen pusat dan lokal. Aplikasi dan database lokal tersimpan pada $C P U$ yang ada di titik-titik lokasi jalur hauling sesuai aktivitas trailer. Aktivitas trailer atau hauling activity pada proses pengangkutan dan pencampuran batubara antara lain empty travel, loading at ROM, loaded travel, weighing dan dumping to hopper.

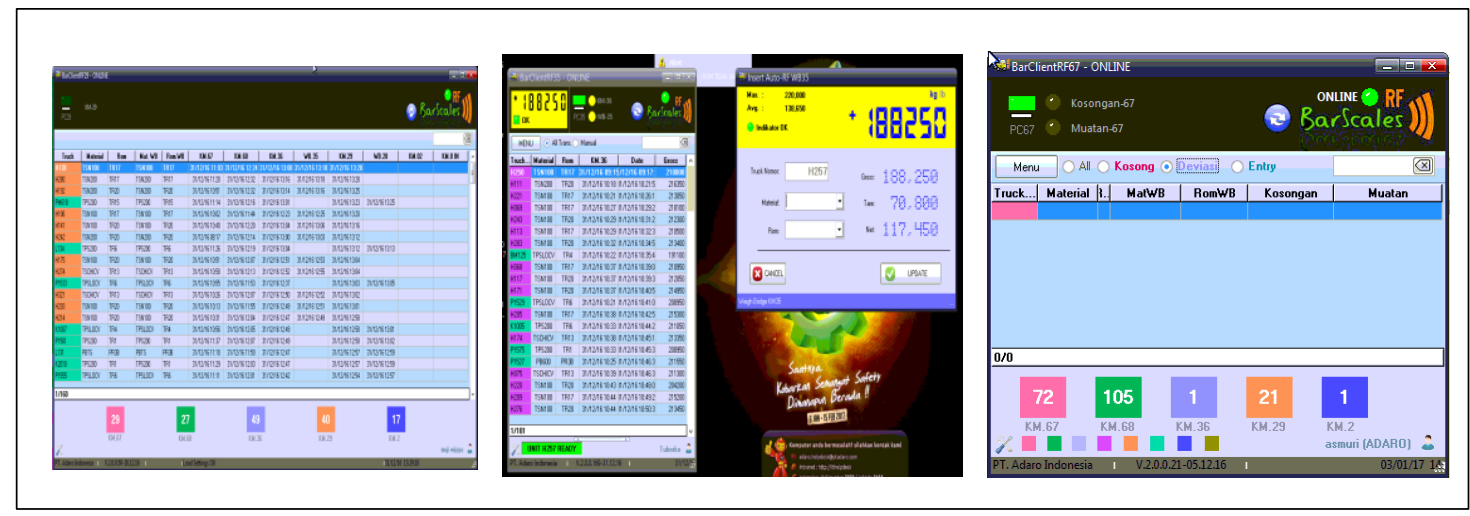

Gambar 6. Contoh tampilan aplikasi pada titik lokasi pembacaan aktivitas trailer

Unit trailer diberikan unique code atau nomor transaksi saat aktivitas empty travel menuju source ROM yang di assign oleh dispatcher sesuai arahan dan perencanaan melalui aplikasi BarClient. Kemudian data quality raw material batubara yang dibawa secara otomatis terupdate pada transkrip transaksi trip tersebut beserta source/ROM location raw material. Data quantity atau tonase batubara akan ter record saat unit trailer melakukan proses penimbangan di jembatan timbang sebelum mengarah ke terminal pemrosesan atau pelabuhan. Selain insert tonnage via aplikasi pada transkrip transaksi, di jembatan timbang juga dilakukan validasi akhir raw material dan source ROM location dengan data pembanding manual yaitu konfirmasi melalui komunikasi radio antara weighbridge operation crew dengan driver trailer yang bertugas. Pada saat tiba di pelabuhan atau terminal pemrosesan, unit trailer akan diarahkan sesuai dengan raw material yang dibawa untuk dumping pada hopper yang sesuai. Hopper adalah bak penampung yang terhubung dengan crusher. Informasi pengarahan unit trailer menggunakan LED display board yang berisi destination list hopper yang aktif yang disesuaikan dengan actual running crusher, skema pengisian tongkang dan line conveyor yang aktif untuk mengisi tongkang dengan batubara yang sudah menjadi product (crushed). Aplikasi BarClient di terminal pemrosesan membantu dispatcher untuk mendeteksi dan merecord hopper location sebagai end transaction dari trip serta mendownload kumpulan transaksi trip yang mengisi tongkang melalui line conveyor secara langsung dari unit trailer yang dumping (bypass) sesuai jam pengisian tongkang. Selain proses insert dan penggabungan data transaksi, tiap trailer yang melewati reader akan terecord data stamp time (waktu pada saat tagger pada trailer terdeteksi oleh reader atau saat trailer melewati titik reader). 


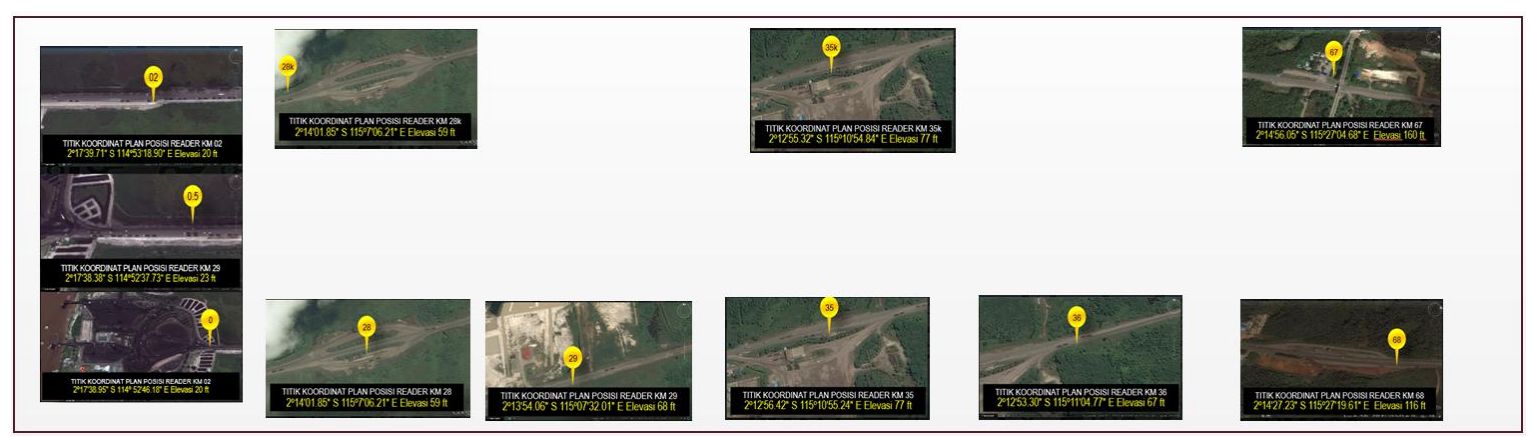

Gambar 7. Penempatan reader dan aplikasi pada jalur aktivitas trailer

Komponen jaringan atau komunikasi data terhubung dari setiap reader menuju ke database pusat. Setiap reader yang ditempatkan di tiap titik disesuaikan dengan fungsi nya. Data yang dihasilkan antara interaksi reader dan tagging card diproses secara online dan real time (Online Transaction Processing) dan tersimpan di database lokal maupun database pusat. Data dari hauling activity yaitu data kuantitas-kualitas raw material batubara yang dibawa, data identitas unit dan data parameter source and destination dihasilkan dengan cepat dan diproses secara langsung melalui sistem OLTP.

Ke semua data hauling activity dikumpulkan dari output interaksi tagging card pada unit trailer dengan masing-masing stamp/reader saat melakukan hauling activity, data tersebut berbentuk transkrip transaksi produksi yang tersimpan di database pusat. Transaksi akhir dari satu trip trailer melakukan hauling activity adalah saat raw material batubara yang di-assign telah selesai melakukan proses penumpahan / dumping pada hopper yang direncanakan.

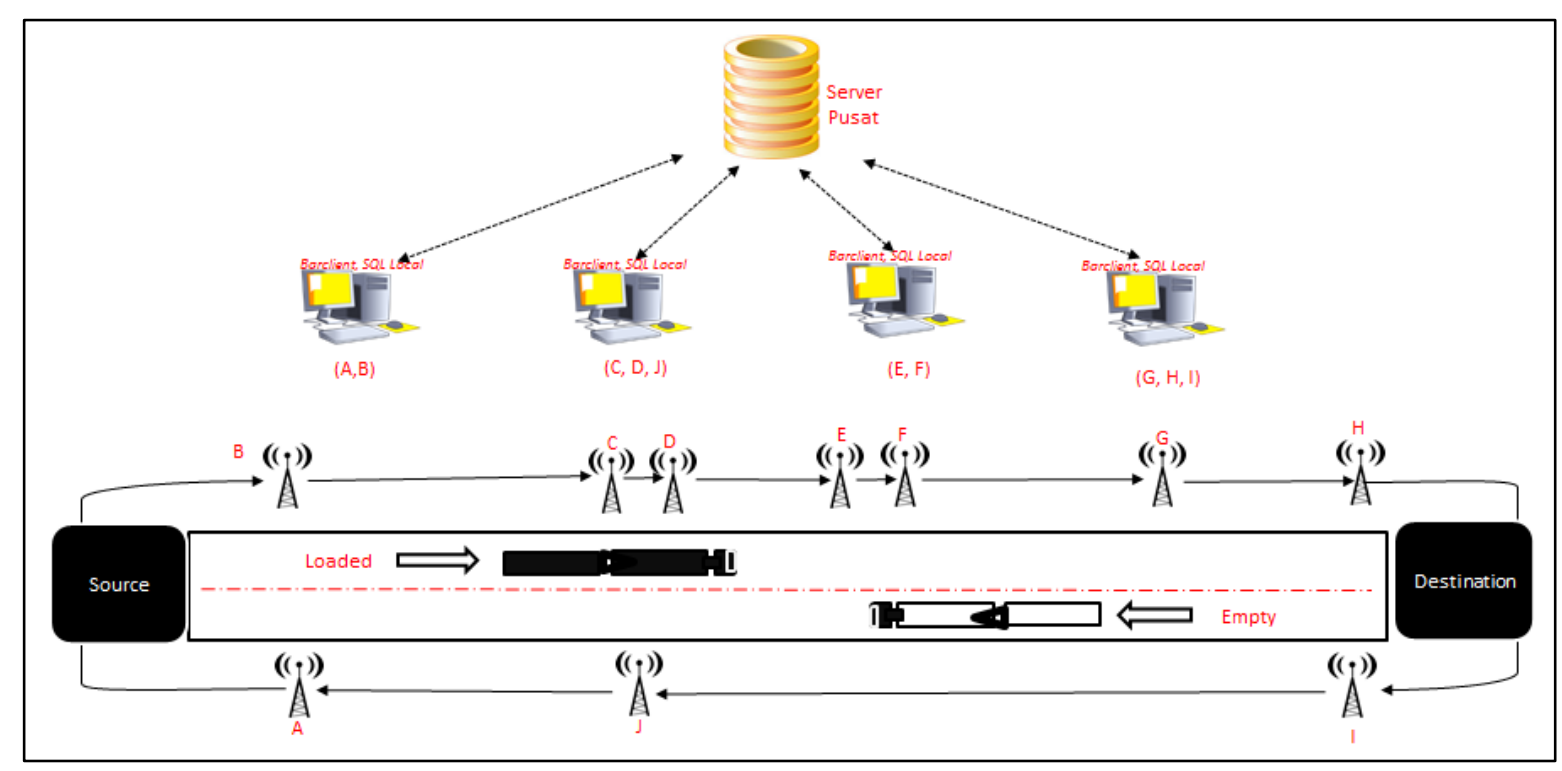

Gambar 8. Ilustrasi konfigurasi posisi hardware serta topologi data dan jaringan

Sistem yang ada sangat bergantung pada kehandalan jaringan dan supply listrik. Agar proses recording, monitoring dan optimizing tetap bisa dilakukan serta data transaksi tidak error ataupun hilang maka dibuat back up sistem jaringan (backhaul) dengan membangun backup networking menggunakan PtP (point to point) wireless long range dengan jangkauan $\pm 100 \mathrm{~km}$ dengan airfiber frekuensi 5 Ghz. Perfomance jaringan juga ditarget dengan menjaga Service Level Agreement (SLA) di angka 99\% agar komunikasi data tidak terputus. Untuk perangkat hardware dan software dilakukan inspeksi dan maintenance baik periodik maupun preventive. Recovery data juga dilakukan secara terjadwal pada database pusat dan lokal. Untuk mengenal dan memprediksi 
potensi kegagalan dari produk atau proses yang dihasilkan sistem ini, juga disusun FMEA (Failures Mode and Effect Analysis). Semua proses dideskripsikan kemudian dipetakan potensi kegagalan nya lalu dihitung RPN (Risk Priority Number) nya.

$$
\text { RPN }=\text { Severity } x \text { Occurance } x \text { Detection }
$$

$$
\begin{array}{ll}
\text { Severity } & =\text { nilai dampak } \\
\text { Occurance } & =\text { nilai kemungkinan } \\
\text { Detection } & =\text { nilai deteksi }
\end{array}
$$

Aplikasi monitoring buatan yang dibuat dan dikembangkan bernama Hauling Tracking System (HTS). Aplikasi ini dibuat dalam jaringan lokal dan dapat diakses oleh semua dispatcher dan team yang terlibat dalam rantai pasok pengiriman batubara. Informasi online yang disajikan dalam dashboard ini antara lain :

- Data inventory quantity dan quality raw material batubara yang ada di ROM

- Posisi alat angkut (truck/trailer) dan alat muat (loader)

- Hopper \& conveyor condition serta status real time nya

- Barge loading schedule
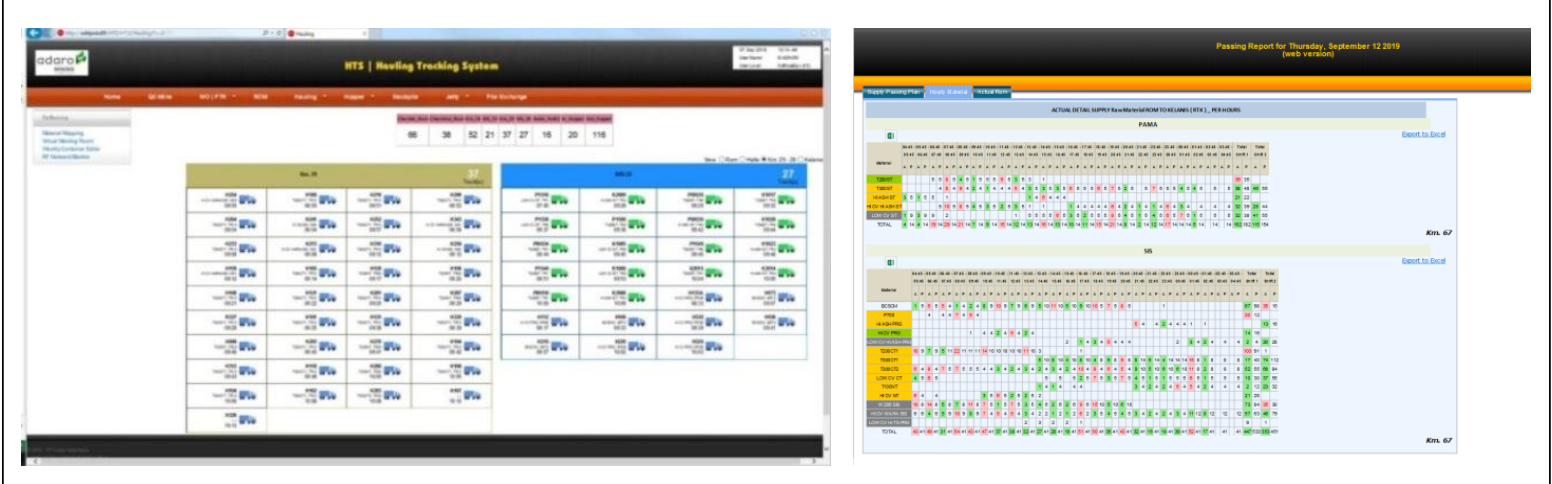

Gambar 9. Dashboard, fitur real time monitoring loaded raw material

Informasi yang ada pada aplikasi monitoring adalah data primer dan sekunder. Data primer ialah data yang dibaca oleh RFID hardware lalu disimpan, diolah dan digabungkan oleh software/aplikasi dan ditampilkan dalam bentuk tabel, chart ataupun grafik. Adapun data sekunder ialah data input atau informasi yang berasal dari proses sebelum dan sesudah hauling.

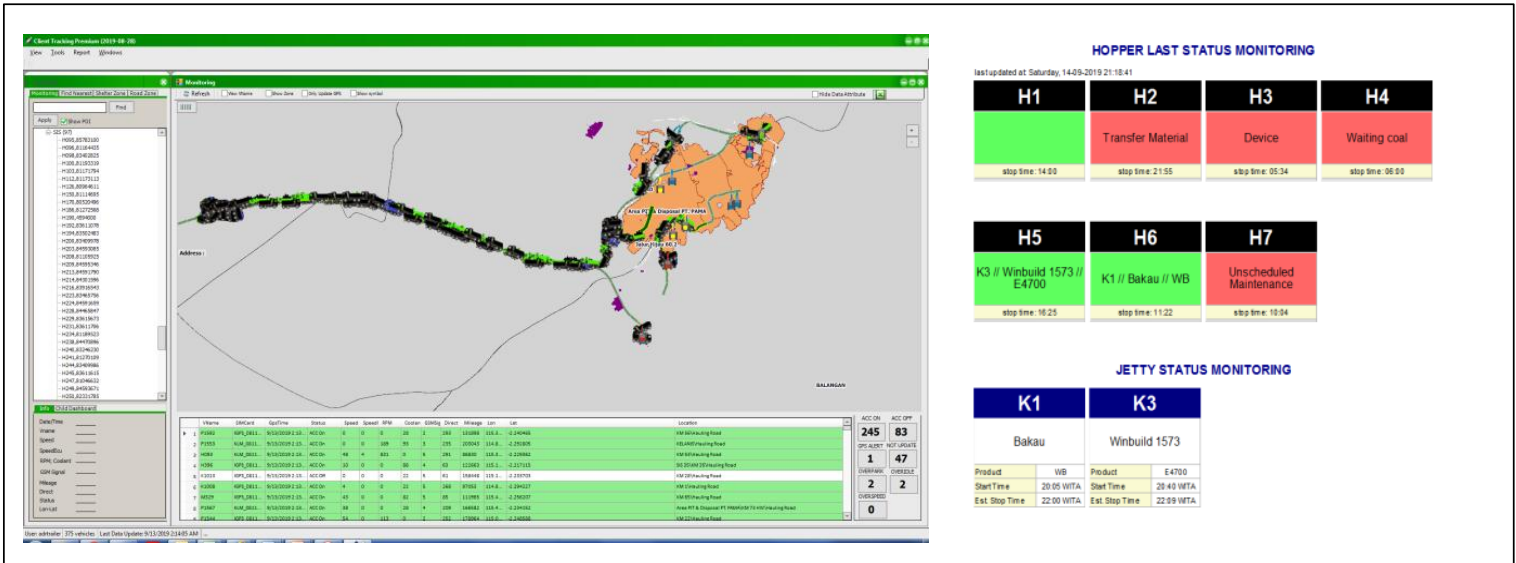

Gambar 10. Dashboard pemantauan posisi unit trailer, crusher and barge status monitoring 
Fitur monitoring pada HTS juga dilengkapi dengan dashboard GPS (Global Positioning System) untuk mengetahui posisi unit trailer di jalur dan unit loader di ROM. Fitur monitoring berikutnya yang ada pada HTS adalah dashboard mirroring dari SCADA (Supervisory Control and Data Acquisition) yang ada pada terminal fasiltas pemrosesan batubara dan pengisian tongkang pelabuhan Km 0. Fitur ini dipakai untuk mensinkronkan supply batubara yang telah direncanakan dengan kondisi running hopper, crusher dan line conveyor saat pengisian tongkang yang sedang sandar. Fitur ini digunakan selama 24 jam operasional untuk mencocokan match factor yang optimum antara supply trailer dengan mesin crusher.

\section{KESIMPULAN}

Pengaplikasian sistem RFID dan aplikasi monitoring buatan memberikan benefit utama yaitu pemantauan posisi, distribusi dan last update dari supply passing coal hauling secara online yang dapat dimonitor oleh dispatcher yang tersebar di beberapa lokasi sepanjang jalur hauling serta pihak-pihak lain yang berada pada rantai proses pengiriman batubara. Dengan adanya kombinasi tools ini juga memberikan benefit terukur secara cost dan quality, antara lain :

- Meningkatkan presisi kuantitas dan kualitas campuran batubara menjadi 100\% karena menghilangkan deviasi pengangkutan raw material dan proses pelaporan serta pencatatan yang manual. Sistem ini juga mempercepat waktu pembuatan laporan dan kalkulasi data terkait coal quality report.

- Dengan sistem integrasi dan perhitungan yang dibuat, proses analisa perfomance indicator alat angkut trailer (cycle time) dapat menghemat lead time sebesar $90 \%$ dari metode lama atau mode manual. Metode lama adalah dengan menggunakan timesheet atau form yang dicatat oleh operator trailer sedangkan metode yang baru adalah menggunakan data stamp reader terintegrasi yang diolah dan dianalisa. Human error dapat dihilangkan dari penggantian metode ini dan dengan data yang valid and reliable proses perbaikan dapat dilakukan lebih cepat dan tepat sasaran.

- Walaupun tidak sedetail dan selengkap fitur pada produk Fleet Management System (FMS) yang ada di pasaran global umumnya serta mining industry khususnya, tetapi biaya investasi dan maintenance sistem yang dikembangkan ini hanya $15 \%$ dibandingkan harga produk FMS di industri, ditambah keuntungan bahwa aplikasi yang dibuat ini lebih compatible dan dapat dilakukan modifikasi custom sesuai kebutuhan dan bisnis proses yang ada.

- Meningkatkan produktivitas alat angkut trailer dan utilisasi crusher dengan adanya kontrol match factor dan optimasi supply trailer ke crusher.

\section{DAFTAR PUSTAKA}

Kaur, M., Manjeet, S., Neeraj, M., Parvinder, S., (2011). RFID Technology Principles, Advantages, Limitation and Its Applications, International Journal of Computer and Electrical Engineering, Vol.3, No.1, February, 2011, 151-153.

PT Adaro Indonesia. (2017). Manual BarscalesRF V.2.0, Tanjung Tabalong

PT Adaro Indonesia (2017). Technical Standard Adaro Indonesia PAH-04-001. PT Adaro Indonesia. Tanjung Tabalong 